\title{
Company Law
}

\section{Piercing the conceptual veil of voluntary assumption of responsibility by Dr Paula Giliker}

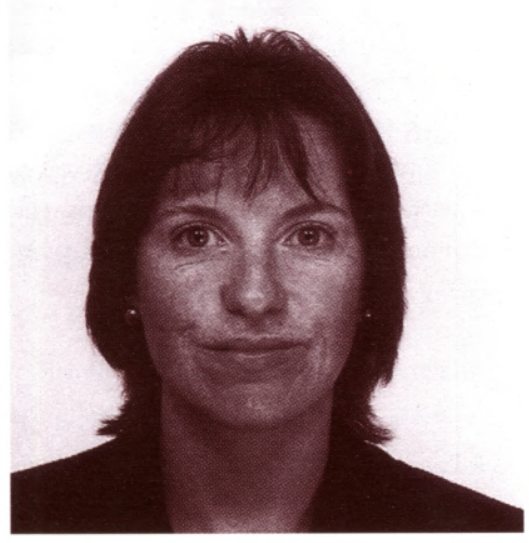

Dr Paula Giliker

The recent House of Lords case of Williams $\checkmark$ Natural Life Health Foods Ltd [1998] 2 All ER 577 once again raises the question of the extent to which a plaintiff will be able to recover damages in tort for pure cconomic loss suffered due to the negligence of another. As stated by Heatherington (commenting on the Court of Appeal decision in Amicus Curiae, Issue 3, at p. 21), this case concerned a claim by two franchisces who had invested their limited capital in a health food shop in Rugby under a franchise agreement with the defendant company.

\section{PRACTICAL JUSTICE}

'Practical justice' offers little indication to stressed lower court judges as to when, on a given set of facts, the defendant will be deemed to have assumed responsibility for the service to the other party, particularly where, as in all four House of Lords decisions, we are dealing with indirect recipients/beneficiaries of the service. Questions yet to be answered are:

- What degree of intervention will be necessary for a defendant to have assumed responsibility for the service?

- What degree of personal contact will be required?

- Will we be left with degrees of 'indirectness'? and if so

- What is the distinguishing factor?

They had been sent, and had relied upon, financial projections prepared by the company, which were largely based on the experience of the second defendant (the managing director of the company) in his own shop in Salisbury. Unfortunately for the plaintiffs, the figures were negligently prepared and their own business failed, having traded at a loss for 18 months. The defendant company being insolvent, the appeal focussed on the alleged responsibility of the managing director, $\mathrm{Mr}$ Mistlin, for the figures.

The House of Lords overturned the Court of Appeal decision ([1997] 1 BCLC 131) which found Mr Mistlin liable for the misleading statements made to the plaintiffs. In his leading judgment, Lord Steyn held that under the 'extended Hedley Byrne principle', a director would only be directly responsible in tort if he or she assumed personal responsibility for the provision of information to the client and this had not occurred on the facts of the case. Mr Mistlin was therefore not liable for the plaintiffs' resulting losses.

In my view, this judgment raises two significant points:

(1) it recognises once again the importance of limited liability protection in company law; and

(2) it does not find such protection necessarily inconsistent with tortious liability against individual directors, although it is said to occur rarely.

More importantly the House of Lords clearly follows the more flexible approach, recently adopted towards pure economic loss, which results from the negligent performance of services (see White $v$ Jones [1995] 2 AC at p. 207, Henderson v Merritt Syndicates Ltd [1995] 2 $\mathrm{AC}$ at p. 145 and Spring ${ }_{V}$ Guardian Assurance plc [1994] 2 AC at p. 296).

This paper will examine the House of Lords' treatment of the two issues raised above and assess the extent to which this judgment increases our understanding of the central concept of 'voluntary assumption of responsibility'.

\section{LIMITED LIABILITY}

It is trite law that incorporation of a company will generally protect a director from personal liability and in such circumstances, the company will be the correct person to sue (see Salomon v A Salomon \& Co Ltd [1897] AC 22). Of course this is how the plaintiffs commenced the action, but the windingup of the company forced them to join the managing director of the company to retain a viable chance of gaining compensation. Whilst Langley J, at first instance ([1996] 1 BCLC at p. 288), and the majority of the Court of Appeal did find $\mathrm{Mr}$ Mistlin personally liable to the plaintiffs, this was not considered to challenge the traditional perception of corporate responsibility. As Langley J states at p. 301 :

the status of Mr Mistlin as the controller of the defendant company is itself of limited relevance and, absent exceptional circumstances, he is entitled not to be deprived of the benefit of limited liability when acting in the business of the defendant company. It is personal liability for the tort, not the company, which is required to render a director liable.'

The key was not therefore responsibility via the company law mechanism of control, but personal liability whereby the conduct of the director established a duty of care towards the individual concerned.

Herc, the lower courts had found such a duty of care, focussing on the fact that the figures on which the plaintiffs relied had been largely based on Mr Mistlin's own business in Salisbury (the other franchises had not been in operation long enough to give satisfactory figures). Equally Mr Mistlin was deemed to be a major 'behind the scenes' influence, supporting the actions of his fellow directors. Whilst disagreeing with these findings, the House of Lords (at p. 582) supported the key distinction between corporate responsibility and the personal liability of directors:

'a company is a separate entity, distinct from its directors, servants or other agents in order to establish personal liability under the principle of Hedley Byrne ... [t]here must have been an assumption of responsibility such as to create a special relationship with the director or employee himself.' 


\section{VOLUNTARY ASSUMPTION OF RESPONSIBILITY}

Undoubtedly the most interesting aspect of the case is the House of Lords' further endorsement of the concept of 'voluntary assumption of responsibility' lying at the heart of the courts' analysis of recovery for pure economic loss in the law of tort. Lord Steyn (at p. 581) views it - while notably refraining from distinguishing acts from statements under the extended Hedley Byrne principle - as the:

'rationalisation or technique adopted by English law to provide a remedy for the recovery of damages in respect of economic loss caused by the negligent performance of services.'

On the facts, the House of Lords held that $\mathrm{Mr}$ Mistlin was not sufficiently involved in the transaction to assume personal responsibility towards potential franchisees. Indeed, he had had no personal contact with the plaintiffs, who had dealt with the franchise director and corresponded on the company's notepaper. As such, he did not go beyond his role as managing director. Directors will no doubt be relieved at this delineation of their responsibilities in law.

The case's significance, however, lies in its view that the question is to be resolved by reference to the concept of 'voluntary assumption of responsibility'. This must be of concern to all those who are unsure as to the actual meaning of this concept. What exactly must you do to assume responsibility towards another? It has indeed been criticised, both judicially and academically, as a concept riddled with ambiguity and uncertainty (see, for example, Barker (1993) 109 LQR at p. 461, Lord Griffiths in Smith v Eric S Bush [1990] 1 AC at p. 831 and 862, Lord
Oliver in Caparo plc v Dickman [1990] 2 AC 605 at p. 637 and, more recently, Lord Mustill dissenting in White $v$ Jones at p. 288). Lord Roskill in Caparo plc v Dickman (at p. 628) confesses to:

'find [ing] considerable difficulty in phrases such as "voluntary assumption of

responsibility" unless they are to be explained as meaning no more than the existence of circumstances in which the law will impose a liability upon a person making the allegedly negligent statement to the person to whom that statement is made; in which case the phrase does not help to determine in what circumstances the law will impose that liability or indeed, its scope.

The House of Lords rejects such criticisms and follows Lord Goff's endorsement of the concept in the Spring, Henderson and White $v$ Jones cases. However Lord Steyn's response is somewhat disappointing. Rather than addressing the conceptual misgivings expressed in relation to the practical application of the concept, his Lordship comments

p. 584 that:

'Coherence must sometimes yield to practical justice ... while the present structure of English contract law remains intact the law of tort, as the general law, has to fulfil an essential gap-filling role.

This is reminiscent of Lord Goff's view in White v Jones of tort as an instrument of practical justice and must be subject to similar criticisms. 'Practical justice' offers little indication to stressed lower court judges as to when, on a given set of facts, the defendant will be deemed to have assumed responsibility for the service to the other party, particularly where, as in all four House of Lords decisions, we are dealing with indirect recipients/ beneficiaries of the service. Questions yet to be answered are:
- What degree of intervention will be necessary for a defendant to have assumed responsibility for the service?

- What degree of personal contact will be required?

- Will we be left with degrees of 'indirectness'? and if so,

- What is the distinguishing factor?

\section{CONCLUSION}

The House of Lords' judgment in Williams raises interesting points of law and highlights the current trend in the development of recovery for pure economic loss in the law of tort. Whilst affirming that directors' responsibility in tort will be confined to 'rare' occasions when he or she assumes personal responsibility beyond the role of director, the House of Lords turns once again to the concept of 'voluntary assumption of responsibility' as the key resolving principle. This will be determined according to the facts of each case. Some concern must, however, be expressed as to whether this provides adequate guidance to lower courts and litigants alike. What key factors mark out an assumption of responsibility? When will a director need to ensure care is taken not to be negligent? Should tort law intervene to resolve the perceived deficiencies of contract law or should contract law, with the assistance of legislation, be left to put its own house in order? In my view, Williams stands as a missed opportunity to address the concerns underlying 'voluntary assumption of responsibility' and give much-needed clarity to this area of law. (c)

\section{Dr Paula Giliker}

Barrister, Lecturer in Law at London Guildhall University

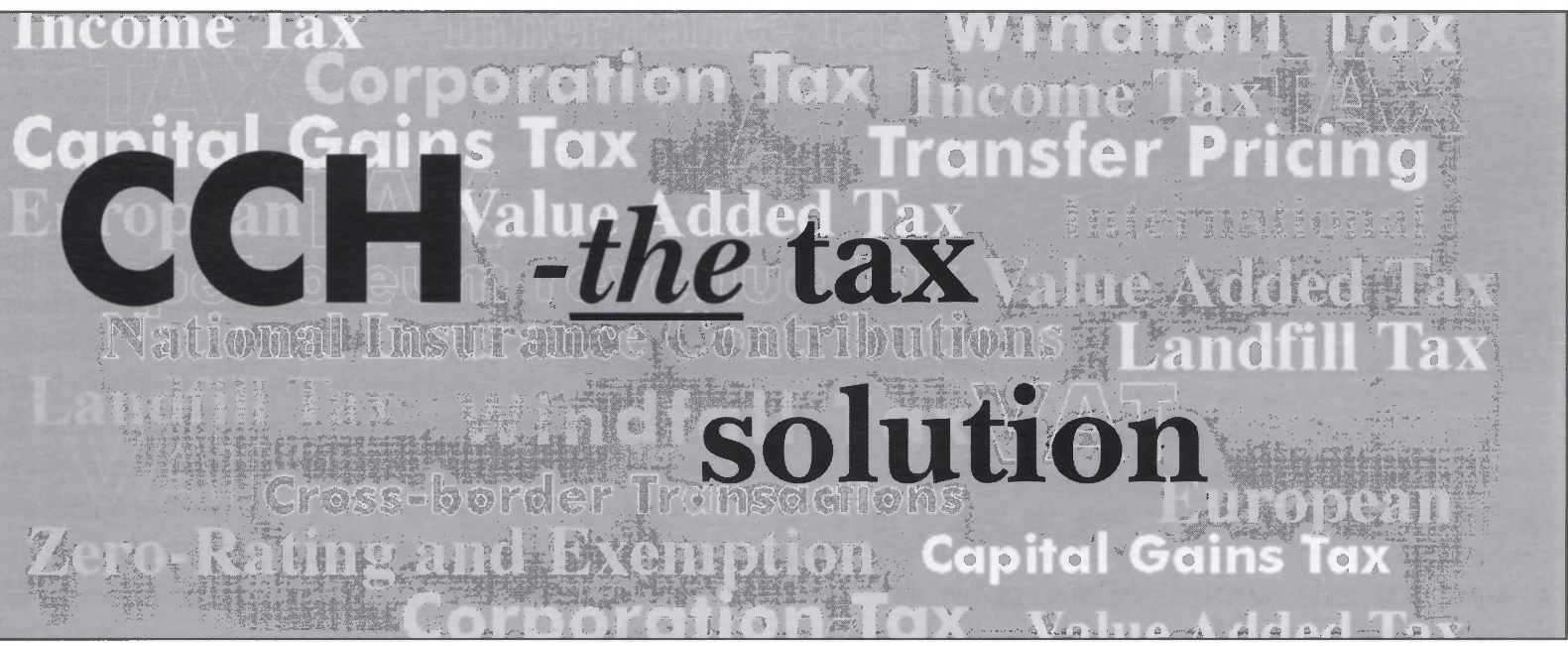

